\title{
Effects of raw or extruded legume seeds on some functional and morphological gut parameters in rats
}

\author{
H. Leontowicz', M. Leontowicz', H. Kostyra' ${ }^{2}$, G. Kulasek', \\ M.A. Gralak' ${ }^{1}$ R. Krzemiński' and M. Podgurniak ${ }^{1}$ \\ 'Department of Physiology, Biochemistry, Pharmacology and Toxicology, \\ Faculty of Veterinary Medicine, Warsaw Agricultural University \\ Nowoursynonska 166, 02-787 Warsaw, Poland \\ 'Division of Food Science, Institute of Animal Reproduction and Food Research, \\ Polish Academy of Sciences \\ Tuwima 10, 10-718 Olsztyn, Poland
}

(Received 17 March 2000; accepted 22 January 2001)

\begin{abstract}
The effects of extruding soya bean, faba bean and pea seeds on trypsin inhibitor (TI) and lectin activities, dry matter and protein digestibilities, pancreatic trypsin activity, relative weight of rat internal organs, and microbiology and histology of the jejunum were studied. Wistar rats were fed semipurified diets containing $10 \%$ of legume seeds: raw $(\mathrm{R})$ or extruded at $150^{\circ} \mathrm{C}(\mathrm{E})$. Extrusion reduced $\mathrm{TI}$ activity of soya bean sceds from 31.3 to 23.0 , faba bean from 2.1 to 0.7 , and pea from 2.3 to $0.3 \mathrm{TJU} / \mathrm{mg}$. Extrusion of soya bean seeds also reduced agglutination activity against guinea pig erythrocytes. Extrusion of soya bean, but not of pea and faba bean, improved apparent digestibility of dry matter and protein $(\mathrm{P} \leq 0.01)$. Pancreas weight $(0.392 \% \mathrm{BW})$ and trypsin activity $(0.424 \mathrm{U} /$ total pancreas) were the highest in rats fed the diet with raw soya bean. Extrusion increased $(P \leq 0.05)$ trypsin activity in the pancreas of rats fed on all seeds (mean value 2777 vs $3212 \mathrm{U} / 100 \mathrm{~g}$ protein) and decreased $(\mathrm{P} \leq 0.05)$ total protein content (mean $13.0 \mathrm{vs} 10.6 \mathrm{mg} / \mathrm{pan}$ creas) as well as the relative weight of the pancreas. Significant differences were found between the relative weights of several organs in rats fed on pea, faba bean or soya bean dicts. Extrusion of faba bean reduced the $E$. coll count in the small intestine and tended to decrease damage to intestinal villi.
\end{abstract}

KEY WORDS: trypsin inhibitors, lectins, pancreas, extrusion, digestibility, rats, legumes 


\section{INTRODUCTION}

Plant protease inhibitors (trypsin-TI, chymotrypsin-CHTI), lectins and others factors that have antinutritional properties are present in legumes and limit their feeding usefulness (Liener, 1994). In the small intestine, plant protease inhibitors form insoluble complexes with pancreatic proteases, which in turn are excreted with faeces. A trypsin deficit in the small intestine lowers alimentary protein digestibility and negatively affects body gain of animals. Increasing amounts of $\mathrm{TI}$ in the diet are followed by a deficit of free trypsin, which consequently accelerates homeostatic mechanisms and intensifies exogenous pancreatic function. A high dietary content of TI leads to hypertrophy of the pancreas (Pusztai, 1993), especially in rats, mice, chicken, hamster; it may even lead to cancer (Liener, 1994).

Soya bean trypsin inhibitors are responsible for growth retardation in experimental animals (Kakade et al., 1973), mainly due to losses of sulphur amino acids and decreased digestibility of alimentary protein (Nitsan and Liener, 1976). Growing animals are more sensitive to the losses of pancreatic enzymes than older ones because their pancreatic secretion is not fully developed (Nitsan, 1991).

Lectins are one of the important physiologically active components occurring widely in plant-derived foodstuffs and some, but not all are major antinutrients. In high doses, lectins, which avidly bind to the brush border and disorganize the microvillus membrane of epithelial cells, can seriously damage the small intestine (Pusztai, 1996), impair absorption and transport of nutrients through the intestinal wall (Bardocz et al., 1995; Pusztai and Bardocz, 1995). The depressive effects of lectins present in raw soya bean seeds on rat growth is related to their ability to bind to the microvilli of enterocytes, damaging them damage and/or causing their atrophy.

Considerably higher trypsin inhibitor activity is found in raw soya beans than in peas (range from 35 to 123 and from 0.4 to $34.6 \mathrm{mg} \mathrm{TI} / \mathrm{g}$ protein, respectively) (Huisman and Jansman, 1991). According to Despande (1992) Tl activity in pea seeds and faba bean amounts to $1.5-13$ and $0.7-36 \%$ of the activity found in soyabean, respectively. Lectin activity (HAA) is also greater in raw soyabean meal than in pea seeds and faba bean (Valdebouze et al., 1980).

Both protease inhibitors and lectins are thermolabile and different processes like boiling, toasting, granulation, extrusion/expansion can be applied to decrease their activity and improve the nutritional value of legumes (Van der Poel, 1990; Despande, 1992; Qin et al., 1996; Armour et al., 1998). High pressure and temperature during extrusion also produce physicochemical changes in proteins, starch and other components of legume seeds, affecting their final nutritional value.

The objective of this study was to compare the effects of $10 \%$ supplement to diets of raw or extruded $\left(150^{\circ} \mathrm{C}\right)$ legume seeds (faba bean, pea and soya bean) on 
protein digestibility, pancreas trypsin activity, bacteriology and histology of the jejunum and relative organ weights in growing rats.

\section{MATERIAL AND METHODS}

\section{Animals, diets and experimental procedure}

Male Wistar rats, of an initial body weight of $135 \pm 13 \mathrm{~g}$ were divided randomly into six groups of ten. During four weeks, each group received one of six semipurified diets (Table 1) containing $10 \%$ of crushed seeds: faba bean (Vicia faba L.) var. Nadwiślański (F), spring pea (Pisum sativum L.) var. Fidelia (P) or soya bean (Glycine max. L.) imported from Brazil (S), added as raw (R) or extruded (E) at $150^{\circ} \mathrm{C}$ (Insta-Pro 600 single-screw extruder). Exposition time was about $40 \mathrm{~s}$, moisture, about $25 \%$.

The dietary concentration of crude protein is given in Table 3.

Rats were kept in individual plastic cages at a constant temperature $\left(24^{\circ} \mathrm{C} \pm 1^{\circ} \mathrm{C}\right)$ with a 12-h light: dark cycle. Water and feed were provided ad libitum. Feed intake was recorded daily; body weight was recorded once a week. The experimental protocol was approved by the Animal Care Committee of the Warsaw Agricultural University.

Dry matter (DM) and protein digestibilities were estimated in the third week. For this purpose faeces were collected during four days and refrigerated until analysis.

TABLE 1

Composition of the rat diets (\%) containing raw $(R)$ or extruded $(E)$ faba bean $(F)$, pca $(P)$ or soya bean $(\mathrm{S})$

\begin{tabular}{|c|c|c|}
\hline \multirow{3}{*}{ Components } & \multicolumn{2}{|c|}{ Dicts } \\
\hline & Raw & Extruded \\
\hline & $F, P, S$ & $\mathrm{~F}, \mathrm{P}, \mathrm{S}$ \\
\hline Wheat starch & 64.3 & 64.3 \\
\hline Cascin & 10 & 10 \\
\hline Soya bean oil & 10 & 10 \\
\hline Cellulose & 1 & 1 \\
\hline Mineral-vitamin premix ${ }^{3}$ & 4.7 & 4.7 \\
\hline Raw legumes & 10 & - \\
\hline Extruded legumes ${ }^{2}$ & - & 10 \\
\hline
\end{tabular}

NAS (1972)

2 extrusion was performed at $150^{\circ} \mathrm{C}$ 
After four weeks of the experiment the rats were sacrificed by cervical dislocation and the heart, kidney and gastrointestinal tract with pancreas, liver and spleen were isolated. The stomach and small intestine were separated from the mesentery, cut longitudinally and digesta was removed with cold $0.9 \%$ saline. All organs were rinsed with saline, dried with filter paper, and weighed. A two-centimeter section of small intestine, $5 \mathrm{~cm}$ from pylorus, was taken for histology, and another section (about $1 \mathrm{~g}$ ) for bacteriology investigations (except from rats fed diets containing raw and extruded pea (PR and $\mathrm{PE}$ ) because it was not technically possible to carry out this determination in all groups. The pancreas was freeze-dried and stored at $-20^{\circ} \mathrm{C}$ until analysis.

Analyses

Feed and faeces were analyzed for dry matter $\left(105^{\circ} \mathrm{C}\right)$ and nitrogen (KjeltecTecator).

Trypsin inhibitor activity (TIA) in raw and extruded seeds was estimated according to Kakade et al. (1974) as modified by Valdebouze et al. (1980) with $\mathrm{N}$-benzoyl-DL-arginine-p-nitroanilide (BAPNA) as the substrate. The activity of trypsin inhibitors (TI) was expressed in trypsin inhibited units/mg.

For the estimation of lectin activity, proteins were extracted from raw and extruded seeds according to Paredes-Lopez et al. (1989), freeze-dried and used for measurement of haemagglutination activity (HAA). The test of agglutination of guinea pig red blood cells was performed according to Liener (1989). The agglutination caused by protein extracts was measured after $3 \mathrm{~h}$.

\section{Trypsin activity of the pancreas}

Protein content and trypsin activity were estimated in freeze-dried pancreas homogenized in saline. Total protein was determined according to Lowry et al. (1951). Trypsin activity in the pancreas was determined after enterokinase activation, using BAPNA as a substrate (Erlanger et al., 1961); one unit of trypsin activity was defined as the amount of enzyme required to hydrolyze $1 \mu \mathrm{mol}$ of substrate per min and expressed in $\mathrm{U} /$ total pancreas and in $\mathrm{U} / 100 \mathrm{~g}$ protcin. Pancreatic trypsin activity was estimated in 5 rats from each group.

\section{Histology}

For histological investigation, sections of the small intestine (as above) were dehydrated in ethyl alcohol and embedded in paraffin wax, cut at $3 \mu \mathrm{m}$ (Shandom microtome, Cryostat, UK) and stained with haematoxylin and cosin. Histological investigation of the villi was performed by the standard method (Burck, 1975). 


\section{Bacteriology}

A section of the small intestine (about $1 \mathrm{~g}$ ) was homogenized with saline (Stomacher 400-Lab Blender, UK). Following the 10th dilution, samples were applied to enriched agar plates for total bacteria count and to a Mac Conkey's plate for $E$. coli number (Bagiński, 1965). Colony counting was performed after $48 \mathrm{~h}$ of incubation at $37^{\circ} \mathrm{C}$.

\section{Statistical analyses}

The results of the experiment on rats were statistically analyzed using Statgrafics Plus 6.0 software. Two-way analysis of variance was applied (species $x$ extrusion); Tukey's test was used for comparison of means.

\section{RESULTS}

Trypsin inhibitor activity in raw soya bean $(\mathrm{S})$, faba bean $(\mathrm{F})$ and pea $(\mathrm{P})$ seeds was $31.3,2.3$ and $2.1 \mathrm{TIU} / \mathrm{mg}$, while haemagglutination activity $1: 800$, 1:200 and 1:100, respectively (Table 2 ). After extrusion of seeds TI activity was: $23.0(\mathrm{~S}), 0.7$ (F) and $0.3(\mathrm{P}) \mathrm{TIU} / \mathrm{mg}$, HAA activity was $1: 200,0$ and $1: 100$, respectively.

Among the groups fed on raw legumes, the greatest feed intake and body gain were found in rats fed on the pea, the smallest on the soya bean diet (417 vs 346 and $115 \mathrm{vs} 72 \mathrm{~g}$ ). Extrusion significantly increased feed intake and body gain on soya bean and tended to increase on faba bean diets, while the effect of extrusion of pea was negative but nonsignificant (Table 3 ).

TABLE 2

Trypsin inhibitors and hacmagglutination (HA) titre of protein exiracts from raw and extruded legume seeds $(n=5)$

\begin{tabular}{lccc}
\hline Item & Faba bean & Pea & Soya bean \\
\hline TIU/mg & & & \\
raw seeds & 2.1 & 2.3 & 31.3 \\
extruded seeds & 0.7 & 0.3 & 23.0 \\
HA titre* & & & \\
raw seeds & $1: 100$ & $1: 400$ & $1: 800$ \\
extruded seeds & 0 & $1: 100$ & $1: 200$ \\
\hline
\end{tabular}

* $0=$ no agglutination at $1 \mathrm{mg} / \mathrm{ml}$ concentration of initial protcin extract, $1: 100,1: 400$ and $1: 800$ - dilution of initial protein extract 
TABLE 3

Characteristic of diets and influence of raw or extruded legume seeds on dry matter and crude protein digestibility in rats

\begin{tabular}{|c|c|c|c|c|c|c|}
\hline \multirow{2}{*}{ Diets } & \multirow{2}{*}{$\begin{array}{c}\text { Dry matter } \\
\%\end{array}$} & \multirow{2}{*}{$\begin{array}{c}\text { Crude protein } \\
\text { DM } \%\end{array}$} & \multirow{2}{*}{$\begin{array}{c}\text { Feed intake } \\
\mathrm{g} / 28 \mathrm{~d}\end{array}$} & \multirow{2}{*}{$\begin{array}{c}\text { Body gain } \\
\mathrm{g} / 28 \mathrm{~d}\end{array}$} & \multicolumn{2}{|c|}{ Digestibility, \% } \\
\hline & & & & & dry matter & crude protein \\
\hline $\mathrm{FR}$ & 93.5 & 12.5 & $373.4^{\text {ab }}$ & $83.7^{\text {ab }}$ & $93.1^{\mathrm{b}}$ & $83.9^{\text {st }}$ \\
\hline $\mathrm{FE}$ & 93.2 & 12.8 & $425.5^{\circ}$ & $94.4^{\mathrm{bc}}$ & $93.2^{\mathrm{b}}$ & $85.5^{\text {bo }}$ \\
\hline PR & 93.1 & 13.2 & $416.8^{\circ}$ & $114.8^{\mathrm{d}}$ & $93.3^{b}$ & $85.3^{\text {hc }}$ \\
\hline $\mathrm{PE}$ & 93.4 & 13.7 & $408.7^{\mathrm{bc}}$ & $104.4^{\mathrm{dd}}$ & $93.3^{b}$ & $86.9^{\circ}$ \\
\hline SR & 93.4 & 13.7 & $346.3^{\mathrm{a}}$ & $72.3^{\mathrm{a}}$ & $91.2^{\mathrm{3}}$ & $82.4^{a}$ \\
\hline $\mathrm{SE}$ & 92.6 & 14.7 & $408.7^{\mathrm{bc}}$ & $99.1^{\mathrm{bcd}}$ & $92.9^{\mathrm{b}}$ & $85.6^{\mathrm{hc}}$ \\
\hline
\end{tabular}

a. b.c.. - $P \leq 0.05$

Dry matter (DM) digestibility was the lowest in rats fed the SR diet $(P \leq 0.01)$ and did not differ among the others. Crude protein digestibility was also lower $(\mathrm{P}<0.01)$ in $\mathrm{SR}$ than in other groups, except in FR. Extrusion of soya bean increased both dry matter and crude protein digestibility $(\mathrm{P} \leq 0.01)$ but had no significant effect when applied to field bean and pea (Table 3).

In rats fed the SR diet, the relative weight of the pancreas and pancreatic total protein content were higher $(\mathrm{P} \leq 0.01)$ than in other groups and equaled $0.392 \%$ and $15.3 \mathrm{mg} /$ pancreas, respectively (Table 4). Extrusion of soya bean and faba bean decreased pancreatic relative weight, but had no effect on rats fed diets containing pea seeds. There was a significant decrease of total protein content in the pancreas of rats fed the diets with extruded soya bean ( $15.3 \mathrm{vs} 9.5 \mathrm{mg} /$ pancreas) and extruded pea (12.1 vs $8.7 \mathrm{mg} /$ pancreas) $(\mathrm{P} \leq 0.01)$ but not the faba bean diet.

In rats fed raw legumes, total pancreatic trypsin activity was significantly higher on the SR than FR diet, while it did not differ among rats fed extruded legumes. Extrusion tended to decrease pancreatic trypsin activity in soya bea$\mathrm{n}$ - and pea-fed rats. When calculated as specific activity (U/100 g protein) the only significant difference was between the FR and SE groups (2601 and $3449 \mathrm{U} / 100 \mathrm{~g}$, respectively) while in all groups extrusion increased TIA nonsignificantly (Table 4). The mean effect of extrusion on digestibility and pancreas parameters (except trypsin activity in total pancreas) was statistically significant (Table 5).

There were no differences in mean trypsin activity and pancreatic protein content among rats fed on diets with different legume seeds (Table 5). Trypsin activity ranged from 2723 (diets with faba bean) to $3163 \mathrm{U} / 100 \mathrm{~g}$ protein (diets with pea).

Extrusion of legumes increased $(\mathrm{P} \leq 0.05)$ mean pancreatic trypsin activity from 2777 to $3212 \mathrm{U} / 100 \mathrm{~g}$ protein and decreased its protein content from 13.0 to 10.6 $\mathrm{mg} /$ pancreas (Table 5). 
TABLE 4

Protein concentration and trypsin activity in pancreas of rats fed diets with raw (R) or extruded (E) legume seeds $(n=5)$

\begin{tabular}{|c|c|c|c|c|c|}
\hline \multirow[b]{2}{*}{ Diets } & & \multirow{2}{*}{$\begin{array}{l}\text { Pancreas } \\
\% \text { body } \\
\text { weight }\end{array}$} & \multirow{2}{*}{$\begin{array}{c}\text { Protein } \\
\mathrm{mg} / \text { pancreas }\end{array}$} & \multicolumn{2}{|c|}{ Trypsin activity } \\
\hline & & & & U/total pancreas & $\mathrm{U} / \mathrm{l} 00 \mathrm{~g}$ protein \\
\hline Raw & Faba bean & $0.339^{\circ}$ & $11.6^{\mathrm{bc}}$ & $0.300^{\mathrm{a}}$ & $2601^{a}$ \\
\hline Extruded & & $0.292^{\mathrm{b}}$ & $13.6^{\mathrm{cd}}$ & $0.386^{\mathrm{ab}}$ & $2845^{\text {ab }}$ \\
\hline Raw & Pea & $0.306^{\mathrm{ub}}$ & $12.1^{\mathrm{c}}$ & $0.360^{\mathrm{ab}}$ & $2983^{\mathrm{ab}}$ \\
\hline Extruded & & $0.305^{\text {sh }}$ & $8.7^{\mathrm{a}}$ & $0.294^{\mathrm{a}}$ & $3343^{\mathrm{ab}}$ \\
\hline Raw & Soya bean & $0.392^{\circ}$ & $15.3^{\mathrm{d}}$ & $0.424^{b}$ & $2746^{\mathrm{ab}}$ \\
\hline Extruded & & $0.329^{\mathrm{ab}}$ & $9.5^{\mathrm{ab}}$ & $0.327^{\text {at }}$ & $3449^{\mathrm{h}}$ \\
\hline
\end{tabular}

a. b, c, d $-P \leq 0.05$

TABLE 5

The influence of legume species or treatment on protein concentration and trypsin activity in pancreas of rats, mean values

\begin{tabular}{|c|c|c|c|c|c|c|}
\hline \multirow[b]{2}{*}{ Item } & \multirow{2}{*}{$\begin{array}{c}\text { Pancreas } \\
\% \text { body } \\
\text { weight }\end{array}$} & \multirow[b]{2}{*}{$\begin{array}{c}\text { Protein, } \\
\text { mg/pancreas }\end{array}$} & \multirow{2}{*}{$\begin{array}{c}\text { Trypsin } \\
\text { activity } \\
\text { U/total } \\
\text { pancreas }\end{array}$} & \multirow{2}{*}{$\begin{array}{l}\text { Trypsin } \\
\text { activity } \\
\mathrm{U} / 100 \mathrm{~g} \\
\text { protein }\end{array}$} & \multicolumn{2}{|c|}{ Digestibility, \% } \\
\hline & & & & & $\begin{array}{c}\text { dry } \\
\text { matter }\end{array}$ & $\begin{array}{l}\text { crude } \\
\text { protein }\end{array}$ \\
\hline \multicolumn{7}{|c|}{ Influence of seeds $(n=10)$} \\
\hline Faba bean & $0.316^{\mathrm{a}}$ & $12.6^{\mathrm{a}}$ & $0.343^{\mathrm{a}}$ & $2723^{a}$ & $93.3^{\mathrm{a}}$ & $84.7^{\mathrm{ab}}$ \\
\hline Pea & $0.306^{\mathrm{a}}$ & $10.4^{\mathrm{a}}$ & $0.327^{\mathrm{a}}$ & $3162^{\mathrm{a}}$ & $93.2^{\mathrm{a}}$ & $86.1^{\mathrm{b}}$ \\
\hline Soya bean & $0.361^{\mathrm{b}}$ & $12.4^{a}$ & $0.376^{\mathrm{a}}$ & $3097^{a}$ & $92.1^{\mathrm{b}}$ & $84.0^{4}$ \\
\hline \multicolumn{7}{|c|}{ Influence of treatment $(n=15)$} \\
\hline Raw & $0.346^{b}$ & $13.0^{\mathrm{b}}$ & $0.361^{a}$ & $2777^{\mathrm{a}}$ & $92.6^{4}$ & $83.9^{\mathrm{a}}$ \\
\hline Extruded & $0.309^{n}$ & $10.6^{\mathrm{a}}$ & $0.336^{a}$ & $3212^{b}$ & $93.1^{b}$ & $86.0^{\mathrm{h}}$ \\
\hline
\end{tabular}

$\mathrm{a}, \mathrm{b}-\mathrm{P} \leq 0.05$

Extrusion did not affect relative organ weights (except the pancreas), hence results given in Table 6 are pooled values from rats fed on raw and treated seeds. Species of legume significantly influenced all gastrointestinal segments and organ weights except the liver. Feeding soya bean increased the relative weight of the small intestine, colon + rectum, large intestine, and heart as compared with feeding pea, while feeding faba bean resulted in greater stomach, small intestine, caecum and spleen weights, than feeding pea, and in greater kidney weight than feeding either pea or soya bean. 
TABLE 6

Gastrointestinal segments and organ relative weights (\% BW) in rats fed diets with $10 \%$ faba bean, pea or soya bean $(n=20)$, pooled values for $R$ and $E$ groups

\begin{tabular}{lccc}
\hline Diet & Faba bean & Pea & Soya bean \\
\hline Stomach & $0.551 \leq 0.075^{\mathrm{b}}$ & $0.500 \leq 0.052^{\mathrm{a}}$ & $0.537 \leq 0.076^{\mathrm{ab}}$ \\
Small intestine & $2.561 \leq 0.276^{\mathrm{b}}$ & $2.271 \leq 0.244^{\mathrm{a}}$ & $2.501 \leq 0.298^{\mathrm{b}}$ \\
Caecum $_{\text {Colon+rectum }}$ & $0.396 \leq 0.105^{\mathrm{b}}$ & $0.330 \leq 0.055^{\mathrm{a}}$ & $0.352 \leq 0.12 \mathrm{I}^{\mathrm{ab}}$ \\
Large intestine $^{\mathrm{d}}$ & $0.479 \leq 0.079^{\mathrm{ab}}$ & $0.437 \leq 0.091^{\mathrm{a}}$ & $0.514 \leq 0.119^{\mathrm{b}}$ \\
Kidney & $0.875 \leq 0.151^{\mathrm{b}}$ & $0.767 \leq 0.106^{\mathrm{a}}$ & $0.866 \leq 0.155^{\mathrm{b}}$ \\
Heart & $0.732 \leq 0.063^{\mathrm{a}}$ & $0.656 \leq 0.031^{\mathrm{a}}$ & $0.688 \leq 0.038^{\mathrm{b}}$ \\
Liver & $0.363 \leq 0.040^{\mathrm{ab}}$ & $0.353 \leq 0.026^{\mathrm{a}}$ & $0.393 \leq 0.063^{\mathrm{b}}$ \\
Spleen & $4.384 \leq 0.330^{\mathrm{a}}$ & $4.424 \leq 0.349^{\mathrm{a}}$ & $4.350 \leq 0.358^{\mathrm{a}}$ \\
\hline
\end{tabular}

a, b $-\mathrm{P} \leq 0.05$

${ }^{1}-$ large intestine $=$ caecum + colon + rectum

Total culturable bacteria in the small intestine of rats fed faba bean diets numbered 5.81 and $5.32 \log \mathrm{CFU} / \mathrm{g}$ (for FR and FE, respectively), which is higher than in animals in both soya bean groups (4.81 and $4.85 \log \mathrm{CFU} / \mathrm{g}$ for SR and SE, respectively) (Table 7). The $E$. coli count was the highest in the FR group and significantly higher than in all other groups $(\mathrm{P} \leq 0.05)$.

Extrusion of faba bean reduced the small intestine $E$. coli count (4.62 vs 3.59 $\log \mathrm{CFU} / \mathrm{g}, \mathrm{P} \leq 0.05$ ), while extrusion of soya bean had a smaller effect (3.00 and $2.78 \log$ CFU/g, SR vs SE, respectively).

Histological evaluation of the small intestine of rats fed diets supplemented with faba or soya beans revealed that the most serious changes were observed in rats fed diets with raw soya bean (SR diet). Intestinal villi were partially deprived of endings and epithelium, some villi were damaged and sometimes were detached from the basal membrane. Histological changes were less frequent in the FR- than in SR group. Extrusion of legume seeds decreased the number of animals with damaged villi.

\section{DISCUSSION}

The results of our experiment are in general agreement with earlier data showing greater antitrypsin and haemagglutinating activity of raw soya bean than of faba bean and pea, and its negative effects on rat performance (feed intake, body gain), dry matter and protein digestibility, and on measurements related to pancreatic function, as compared with animals fed raw faba bean and pea. 
TABLE 7

Microbiological parameters of small intestine in rats fed diets with $10 \%$ soya bean or faba bean $(\mathrm{n}=10)$

\begin{tabular}{lccc}
\hline $\begin{array}{c}\text { Diets with legume } \\
\text { sceds }\end{array}$ & $\begin{array}{c}\text { Total culturable } \\
\text { bacteria, log CFU*/g }\end{array}$ & $\begin{array}{c}\text { E. coli } \\
\log \text { CFU/g }\end{array}$ & $\begin{array}{c}\text { E. coli/total } \\
\text { culturable bacteria counts }\end{array}$ \\
\hline Faba bean, raw & $5.81 \leq 0.93^{\mathrm{b}}$ & $4.62 \leq 1.03^{\mathrm{b}}$ & 0.795 \\
extruded & $5.32 \leq 0.86^{\mathrm{ab}}$ & $3.59 \leq 1.11^{\mathrm{a}}$ & 0.675 \\
Soya bean, raw & $4.81 \leq 0.80^{\mathrm{a}}$ & $3.00 \leq 0.44^{\mathrm{a}}$ & 0.624 \\
extruded & $4.85 \leq 1.12^{\mathrm{a}}$ & $2.78 \leq 0.97^{\mathrm{a}}$ & 0.573 \\
\hline
\end{tabular}

a.b.c $-\mathrm{P} \leq 0.05$

* $\mathrm{CFU}$ - colony forming unit

In raw soya bean seeds, lectin and TI activities were much higher than in pea and faba bean seeds and extrusion reduced these activities in all legumes (Table 2). This observation agrees with the drop in TI activity after extrusion of different legume seeds, as well as after autoclaving and boiling, reported by Despande (1992) and Leontowicz et al. (1999).

Faba bean and pea lectins were more sensitive to extrusion than those of soya bean (Table 2). The lack of, or very low agglutination ability of protein extracts from extruded pea seeds and faba beans proves that lectins are inactivated, while according to van der Poel (1990) some lectins can remain fully reactive after thermal treatment. Leontowicz et al. (1999) obtained similar results with soya bean when seeds were extruded in different temperatures or boiled for different times. This points to the greater effectiveness of extrusion as a means of reducing the activity of antinutritional factors when applied to faba beans or peas than to soya.

Trypsin inhibitors and lectins significantly decreased feed intake and body weight of rats fed raw soya bean seeds and nonsignificantly on faba beans (Table 3 ). Inhibition of growth rate and decrease of protein digestibility in animals fed diets containing TI and lectins were also observed by Liener (1994). In our experiment, extrusion of seeds increased dry matter and protein digestibility $(\mathrm{P} \leq 0.01)$ only in group SE as compared with SR (Table 3 ). Lower protein digestibility of raw soya bean may in part have resulted from losses of endogenous protein, rich in sulphur amino acids. Supplementation of sulphur amino acids to rat diets containing $10 \%$ Austrian raw soya bean or faba bean significantly increased feed intake, body gain and improved feed efficiency ratio (Leontowicz et al., 1997; Leontowicz and Kulasek, 1998).

The lack of a significant positive effect of extrusion of faba bean and pea on digestibility parameters and body gain, in spite of inactivation of lectins and protease inhibitors, may result either from their relatively low levels in raw seeds 
or from possible negative effects of thermal treatment on lysine and protein availability (van Barneveld et al., 1994).

Dietary protease inhibitors stimulate hypertrophy and hyperplasia of the pancreas. In rats fed the SR diet, pancreas hypertrophy was observed, and the weight of the pancreas amounted to $0.392 \%$ of body weight (Table 4). Similar effects on the pancreas, but not confirmed statistically, were observed in the group fed the FR diet and also in animals fed the diet with extruded soya bean (SE), which still had considerable TI activity (Table 3). Despande (1992) concluded that to achieve maximum weight gains and protein digestibility in rats fed a soya bean diet, 79$87 \%$ of TI activity should be destroyed, while destruction of $55-69 \%$ of TI is required for elimination of pancreas hypertrophy. In the present study, extrusion of soya bean eliminated only about $27 \%$ of initial Tl activity.

Generally, trypsin activity expressed per unit of pancreatic protein of rats offered diets supplemented with extruded seeds was higher $(\mathrm{P} \leq 0.05)$ than in those fed raw seeds, and a tendency towards higher protein digestibility was observed (Table 4). Pancreas hypertrophy in group SR was accompanied by greater total trypsin activity, $0.424 \mathrm{U} /$ total pancreas (Table 4 ), which may be ascribed to a feedback mechanism stimulated by e.g. CCK, observed in rats fed diets with raw soya bean by Iwai et al. (1988). The total pancreatic protein content was also higher in SR than in SE rats, but the difference was greater than in trypsin activity, which is why trypsin activity expressed per $100 \mathrm{~g}$ protein was smaller in SR than in SE rats (Table 4).

Pancreas hypertrophy observed in rats fed the raw soya bean diet could also have been stimulated by lectins present in soya bean seeds, which was also found by Bardocz et al. (1995). Lectins can induce enlargement of the pancreas and affect pancreatic proteolytic activity. In our previous experiment we showed that a pea-lectin extract given with a semipurified diet for rats in the amount of $5 \mathrm{mg} / \mathrm{day}$, decreased pancreatic trypsin activity from 6412 to $4447 \mathrm{U} / 100 \mathrm{~g}$ protein (Leontowicz et al., 1999).

The total protein content in the pancreas of rats fed the dict with raw soya bean was $15.3 \mathrm{mg} /$ pancreas and was significantly higher than in other groups except $\mathrm{FE}$. The greater protein concentration in the pancreas points to the high activity of this organ. Hypertrophy of the pancreas affects its function or, at least, synthesis and/or secretion of insulin (Pusztai et al., 1991). Extrusion of soya bean and pea decreased $(\mathrm{P} \leq 0.01)$ the protein content of the pancreas (Table 4 ). When evaluating the influence of extrusion on metabolic activity in rat pancreas, it must be emphasized that extrusion significantly limited hypertrophy and total protein content in the pancreas, and simultaneously increased trypsin activity per $100 \mathrm{~g}$ protein (Table 5).

The GI segment and relative organ weights of rats were affected by legume species (Table 6). Relative weights of the stomach, kidncy and large intestine in 
rats fed faba bean diets were greater than on other legumes; these observations are in agreement with results of Rubio et al. (1999). The small intestine, colon and caecum relative weights were also higher in rats fed faba and soya bean diets than in animals fed pea diets. Differences in the content and composition of dictary fibre could also have had some effect on the weight of GI segments (Leontowicz et al. (1999).

There are differences in the toxicity of lectins of different legume species. Lectins of beans (Vicia faba) or peas (Pisum sativum) did not bind to Caco-2 cells in culture or in vivo to brush border cells of the rat intestine and were also non-toxic for higher animals, therefore these legumes may be safely used in the diet (Pusztai, 1996). Phaselous and soya bean lectins are bound avidly by intestinal cells both in culture and in vivo and were found to be nutritionally toxic when included in the diet at high concentrations (Pusztai et al., 1993; Pusztai, 1996). Lectins bind to the microvilli of the epithelium and stimulate the hyperplastic growth of the intestine. They are resistant to proteolytic breakdown, so when released from villus tip cells, they can react with cells in distal parts of the gut-caecum and colon (Pusztai, 1993).

Bacterial overgrowth or colonisation of $E$. coli form bacteria in the small intestine was observed upon feeding raw common bean (Phaseolus vulgaris) by Liener (1989), and was connected with lectin toxicity. Toxicity symptoms occurred when lectins were included in diets at high levels causing substantial overgrowth of bacteria such as E. coli, serious intestinal damage (Pryme et al., 1998), and malabsorption of nutrients (Pusztai et al., 1993). In the present study we did not find a relationship between lectin level in soya bean and faba bean seeds and the $E$. coli count in the small intestine (Table 7) as observed by Pusztai et al. (1993). In other studics, also performed on rats (Leontowicz et al., 1999), we found that pea lectin extract significantly increased total culturable bacterial counts and $E$. coli counts in the jejunum.

Extrusion of seeds had no effect on total culturable bacterial counts and $E$. coli counts in the small intestine of rats fed the diet with soya bean, but in the case of the faba bean diet, the effect on $E$. coli was significant (Table 7).

The greatest morphological changes in villi were found in the small intestine of rats fed diets with raw soya bean. Similar changes were found in other experiments performed on rats fed the semipurified diet with pea lectin extract (Leontowicz et al., 1999). Pea lectins (5 or $15 \mathrm{mg} / \mathrm{d}$ ) reduced crypt depth suggesting reduction of proliferative processes in the mucosa epithelium. Relationships between lectin doses and villi length, width, as well as thinning of the tunica mucosa were observed. Thinning of the mucous layer in the jejunum populated by bacteria and damage to the microvilli of the intestine can be related to bacterial overgrowth, which was stimulated by lectins.

During evaluation of the effects of TI and lectins one has to take into account the presence of other ANFs in legume seeds (Huisman and Jansman, 1991) such as 
tannins, which form complexes with proteins and reduce protein digestibility due to binding, and consequent inhibition of endogenous enzymes (proteinases, amylases) and increased protein secretion (Griffiths, 1986; Jansman, 1993). According to Pastuszewska et al. (1993) true digestibility of protein of different field bean varieties negatively correlates with their tannin content. Tannins from raw faba bean seeds (apart from TI) could also modify trypsin activity in the pancreas (Table 4).

\section{CONCLUSIONS}

Raw soya bean seeds have greater trypsin-inhibiting and haemagglutinating activity and negatively affect animal performance and diet digestibility as compared with raw pea and faba bean. Extrusion practically eliminates (pea and faba bean) or lowers (soya bean) TI and lectin activity and improves (soya bean) or tends to improve (faba bean) animal performance. Some effects of extrusion on the microbiology of the small intestine and on parameters related to pancreatic activity differ among legumes, while trypsin activity per $100 \mathrm{~g}$ pancreatic protein increased in all legumes under study. Legume species, but not extrusion, affects the relative weight of gastrointestinal segments and organs, except the liver. Generally, extrusion has the most pronounced positive effect when applied to soya bean and the least when applied to pea.

\section{REFERENCES}

Armour J.C., Perera R.L.Ch., Buchan W.C., Grant G., 1998. Protease inhibitors and lectins in soya beans and effects of aqueous heat-treatment. J. Sci. Food Agr. 78, 225-23!

Bagiński S., 1965. Microscope Technique (in Polish). PWN, Warszawa (Poland)

Bardocz S., Grant G., Ewen S.W.B., Duguid T.J., Brown D.S., Englyst K., Pusztai A., 1995. Reversible effect of phytohaemagglutinin on the growth and metabolism of rat gastrointestinal tract. Gut 37, 353-360

Burck H.Ch., 1975. Histology Technique (in Polish). PZWL, Warszawa (Poland)

Despande S.S., 1992. Food legumes in human nutrition: A personal perspective. Crit. Rev. Food Sci. Nutr. 32, 333-363

Erlanger B.F., Kokowsky N., Cohen W., 1961. The preparation and properties of two new chromogenic substrates of trypsin. Arch. Biochem. Biophys. 95, 271-278

Griffiths D.W., 1986. The inhibition of digestive enzymes by polyphenolic compounds. In: M. Freedman (Editor). Nutritional and Toxicological Significance of Enzyme Inhibitors in Foods. Plenum Press, New York, pp. 509-516 
Herzig K.H., Bardocz S., Grant G., Nustede R., Folsch U.R., Puszlai A., 1997. Red kidney bean lectin is a potent cholecystokinin releasing stimulus in the rat inducing pancreatic growth. Gut $41,333-338$

Huisman J., Jansman A.J.M., 1991. Dietary effects and some analytical aspects of antinutritional factors in peas (Pisum sativum), common bean (Phaseolis vulgaris) and soya beans (Glycine $\max \mathrm{L}$ ) in monogastric farm animals. A literature review. Nutr. Abstr. Rev., Ser. B 61, 901-921

Iwai K., Fushiki T., Fukuoka S.I., 1988. Pancreatic enzyme secretion mediated by novel peptide: monitor peptide hypothesis. Pancreas 3, 720-728

Jansman A.J.M., 1993. Tannins in feedstuffs for simple-stomached animals. Nutr, Res. Rev. 6, 209236

Kakade M.L., Hoffa D.E., Liener I.E., 1973. Contribution of trypsin inhibitors to the deleterious effects of unheated soybeans fed to rats. J. Nutr. 103, 1172.1178

Kakade M.L.,Rackis J.J., Mc Ghee J.M., Puski G., 1974. Determination of trypsin inhibitor aetivity of soy products. A collaborative analysis of an improved procedure. Cereal Chem. 51, 376-382

Leontowicz H., Gralak M.A., Leontowicz M., Kulasek G.W., Krzemiński R., 1997. Role of sulphur aminoacids in rats fed soybean and faba bean. Bioavailability ' 97 (FECS Number 224), International Conference Centre, Wageningen ('The Netherlands). Book of Abstracts, p. 100

Leontowicz. H., Kostyra H., Leontowicz. M., Kulasck G.W., 1998. The inactivation of legume seed haemagglutinin and trypsin inhibitors by boiling. Recent advances of research in antinutritional factors in legume seeds and rapeseed. Proceedings of the $3^{\text {rd }}$ International Workshop on Antinutritional Factors in Legume Seeds and Rapeseed. Wageningen (The Netherlands), 93, 429-432

Lcontowicz H., Kulasek G., 1998. The natural food-stuffs digestive enzymes inhibitors (in Polish). Med. wet, 54, 159-165

Leontowicz H., Leontowicz M., Biernat M., Gralak M.A., Krzemiński R., Czerwiński J., 1999. The effect of pea lectins on pancreas and jejunum in rats fed semipurified diet. Cost 98 . Effects of antinutrients on the nutritional value of legume diets. 11 Workshop ,Gut as Target of Functional Foods". Budapest (Hungary)

Leontowicz H., Leontowicz M., Kostyra H., Gralak M.A., Kulasek G.W., 1999. The influence of extrusion or boiling on trypsin inhibitor and lectin activity in leguminous seeds and protein digestibility in rats. Pol. J. Food Nutr. Sci. 8, 77-87

Liener I.E., 1989. Control of antinutritional and toxic factors in oil seeds and legumes. In: W.E.W. Lusas, D.R. Erikson, W. Nip (Editors). Food Uses of Whole Oil and Protein Secds. Amer. Oil Chem. Soc., pp. 344-371

Liener I.E., 1994. Implications of antinutritional components in soybean foods. Crit. Rev. Food Sci. Nutr. 34, 31-67

Lowry O.H., Rosebrough A.L., Farr A.J., Randal R.J., 1951. Protein measurement with the folin phenol reagent. J. Biol. Chem. 193, 265-275

Nitsan Z., 1991. Influence of anti-nutritional compounds on dietary protein utilization in various species, as affected by age, diet and feeding regime. In: B.O. Eggum, S. Boisen, Ch. Borsting, A. Danfacr, T. Hvelplund (Editors). Proceedings of $6^{\text {th }}$ International Symposium on Protein Mctabolism and Nutrition. Herning (Denmark), pp. 103-115

Nitsan Z., Liener I.E., 1976. Studies of digestibility and retention of nitrogen and amino acids in rats fed raw or heated soybean meal. J. Nutr. 106, 292-299

Nutrient Requirements of Laboratory Animals, 1972. National Academy of Science, Washington, DC. Messner Academia of Science. Washington, DC 
Pastuszewska B., Ochtabińska A., Grala W., 1993. Nutritional value of protein of ficld beans with different tannin content. In: A.F.B. van der Pocl, J. Huisman, H.S. Saini (Editors). Recent Advances of Research in Antinutritional Factors in Legume Seeds. Wageningen Pers (The Netherlands), pp. 343-362

Paredes-Lopez O., Guevara-Lara F., Schevenin-Pindeo M.L., Montes-Rivera R., 1989. Comparison of procedure to determine protein content of developing bean seeds (Phaseolus vulgaris). Plant Food Hum. Nutr. 39, 137-148

Pusztai A., 1993. Dietary lectins are metabolic signal for the gut and modulate immune and hormone functions. Eur. J. Clin. Nutr. 47, 691-699

Pusz.tai A., 1996. Chemical probiosis: Blockage by food (plant) lectins of infection of the gut with pathogenic bacteria. In: S. Bardocz, F.V. Nekrep, A. Pusztai (Editors). Cost 98. Effects of Antinutrients on the Nutritional Value of Legume Diets. European Commission 3, 1-6

Pusztai A., Bardocz S., 1995. Lectin: Biomedical Perspectives. Taylor and Francis, London

Pusztai A., Ewen S.W.B., Carvalho A.F.F.N., Grant G., Stewart J.C., Bardocz S., 1991. Immune and hormonal effects of dietary lectins. In: Proceedings of the Interdisciplinary Conference on Effects of Food on the Immune and Hormonal Systems. European Food Toxicy III. Zurich, pp. $22-24$

Pusztai A., Grant G., Spencer R.J., Duguid T., Brown D.S., Ewen S.W.B., Peumans W.J., van Damme E.J.M., Bardocz S., 1993. Kidncy bean lectin-induced Escherichia coli overgrowth in the small intestine is blocked by GNA, a mannose-specific lectin. J. Appl. Bacteriol. 75, 360-368

Pryme I.F., Pusztai A., Bardocz S., Ewen S.W.B., 1998. The induction of gut hyperplasia by phytohaemagglutinin in the diet and limitation of tumour growth. Histol. Histopathol. 13, 575-583

Rubio L.A.,Grant G., Daguid T., Brown D., Pusztai A., 1999. Organs relative weight and plasma amino acid concentrations in rats fed diets based on whole legume (faba bean, lupin, chickpea, defatted soybean) seed meals or their fractions. J. Sci. Food Agr. 79, 187-194

Spannagel A.W., Green G.M., Guan D.F., Liddle R.A., Faull K., Reeve J.R., 1996. Purification and characterization of a luminal cholecystokinin-releasing factor from rat intestinal sccretion. Proc. Nat. Acad. Sci. USA 93, 4415-4420

Qin G., Elst E.R., Bosch M.W., van der Poel A.F.B., 1996. Thermal processing of whole soya beans: Studies on the inactivation of antinutritional factors and effects on ileal digestibility in piglets. Anim. Feed Sci. Tech. 57, 313-324

Valdebouze P., Bergeron E., Gaborit T., Delort-Laval J., 1980. Content and distribution of trypsin inhibitors and heamagglutinins in some legume seeds. Can. J. Plant Sci. 60, 695-701

Van Bameveld R.J., Batterham E.S., Norton B.W., [994. The effect of heat on amino acids for growing pigs. 3. The availability of lysine from heat-treated field peas (Pisum sativum cultivar Dundale) determined using the slope-ratio assay. Brit. J. Nutr. 72, 257-275

Van der Poel A.F.B., 1990. Effect of processing on antinutritional factors and protein nutritional value of dry beans (Phaseolus vulgaris L). A review. Anim. Feed Sci. Tech. 29, 179-208 


\section{STRESZCZENIE}

Wplyw surowych lub ekstrudowanych nasion roślin strączkowych na wybrane funkcjonalne i morfologiczne parametry przewodu pokarmowego u szczurów

Badania prowadzono przez 28 dni na 60 szczurach rasy Wistar, karmionych półsyntetycznymi dietami z 10\% udziałem nasion soi (S), grochu (G) lub bobiku (B), surowych (S) lub ekstrudowanych (E) w ekstruderze INSTA-PRO-600 przy $150^{\circ} \mathrm{C}$. Ekstrudowanie spowodowało obniżenie aktywności inhibitorów trypsyny (TI) w nasionach soi z 31,3 do 23,0; bobiku z 2,1 do 0,7 i grochu z 2,3 do 0,3 TIU/mg. Ekstrudowanie soi wpłynęło na obniżenie aktywności aglutynacji erytrocytów świnki morskiej. Ekstruzja nasion soi, lecz nie grochu i bobiku, wpłynęła istotnie na wzrost strawności suchej masy i białka $(\mathrm{P} \leq 0,01)$. Ekstruzja nasion powodowała wzrost $(\mathrm{P} \leq 0,05)$ aktywności trypsyny (średnio 2777 vs $3212 \mathrm{U} / 100 \mathrm{~g}$ białka) i obniżenie $(\mathrm{P} \leq 0,05)$ zawartości białka w trzustce (średnio 13,0 vs 10,6 mg/trzustkę) oraz spadek procentowego jej udziału w masie ciała. Podawanie szczurom diety z surową soją wywołało hipertrofię trzustki $(0,392 \%$ m.c.). Skarmianie diet z 10\% udziałem nasion strączkowych zróżnicowało w istotny sposób względne masy wielu organów wewnętrznych. 